\title{
Penetapan Wali Adhol Dalam Pernikahan (Studi Komparasi Antara Hukum Islam Dan KHI)
}

\author{
Khoirul Fajri \\ Sekolah Tinggi Agama Islam Unggul Indonesia \\ Email: khoirulfajribkls@gmail.com
}

\begin{abstract}
Penelitian ini bertujuan untuk mengetahui; Bagaimana Konsep Wali Adhol Dalam Pernikahan dan dasar hukumnya dalam pernikahan dan Bagaimana Prosedur penetapan wali Adhol dalam Hukum Islam dan KHI. Penelitian ini merupakan penelitian kepustakaan (library research) dengan menggunakan metode Conten Analysis. Adapun sumber primer yaitu Al-Umm, Bidayatul Mujtahid, al-Fiqih Alal Mazahib al-Arba'ah, Hukum Pernikahan Menurut Islam, UU Pernikahan dan Hukum Perdata, UU Kompilasi Hukum Islam No 13 Tahun 2008. Sedangkan sumber sekundernya buku-buku yang berhubungan dengan penelitian. Berdasarkan hasil analis yang penulis lakukan, dapat di simpulkan bahwa: 1) Konsep Wali Adhol dan dasar hukumnya dalam pernikahan Hukum Islam adalah sebagai berikut: a) Golongan hanafiah menyatakan bahwa penyelesaian pernikahan jika walinya adhol adalah melalui seorang hakim sebagai penengah; b) Sedangkan Syafiiyah dan Malikiyah menyatakan bila wali adhal untuk menikahkan anaknya, dalam hal ini wali Aqrabnya, dan mana kala wali ab'ad tidak bisa menggantikannya, maka hak kewaliannya diserahkan kepada wali Hakim; c) Dan hambaliyah menyatakan bila seorang wali adhal dalam menikahkan anaknya maka hak kewalianya akan berpindah dari wali aqrab ke wali ab'ad sampai yang paling jauh, jika masih tetap adhol maka hak kewaliannya diserahkan kepada hakim; 2) Prosedur penetapan wali Adhol dalam Hukum Islam dan KHI, dalam undang-undang no. 1/1974, KHI dan PMA No .30 tahun 2005 yaitu: Pertama, pemanggilan pihak-pihak, yaitu pemohon dan wali, Kedua, usaha perdamaian, Ketiga, pembacaan surat permohonan, Keempat, pemeriksaan persidangan, Kelima, pembacaan hasil penetapan majelis hakim.
\end{abstract}

Key Words: Wali Adhol; Pernikahan; Hukum Islam; KHI

PENDAHULUAN

Pernikahan adalah jalan yang dipilih Allah untuk melestarikan keturunan.Dikeluarkannya Adam dan Hawa dari Surga untuk kemudian ditempatkan di bumi dapat dikatakan sebagai cikal bakal penciptaan manusia oleh Allah SWT.Manusia menurut ajaran agama Islam adalah sebagai pemimpin atau wakil Tuhan di muka bumi.Dalam istilah agama fungsi manusia yang demikian disebut "Khalifah". Misi manusia sebagai khalifah pada pokoknya adalah memelihara dan menciptakan kemaslahatan manusia dalam hubungannya dengan alam semesta, serta memelihara keluarnya dan melindungi serta memberi nafkah sebagaimana firman Allah dalam surat At-Tahrim ayat: 6 yang Artinya: Hai orang-orang yang beriman, peliharalah dirimu dan keluargamu dari api neraka yang bahan bakarnya adalah manusia dan batu; penjaganya malaikat-malaikat yang kasar, keras, dan tidak mendurhakai Allah terhadap apa yang diperintahkanNya kepada mereka dan selalu mengerjakan apa yang diperintahkan (Q.S.66:6)

Sayyid Sabiq menulis dalam bukunya Fikih Sunnah : "Pernikahan adalah suatu cara yang dipilih Allah sebagai jalan bagi manusia untuk beranak, berkembang biak dan melestarikan hidupnya, setelah masingmasing pasangan siap melakukan peranannya yang positif dalam mewujudkan tujuan Pernikahan" (Sayyid Sabiq, 1980). Tuhan tidak mau menjadikan manusia itu seperti makhluk 
lainnya, yang hidup bebas mengikuti nalurinya dan berhubungan antara jantan dan betina secara anarki, dan tidak ada satu aturan. Tetapi demi menjaga kehormatan dan martabat kemuliaan manusia, Allah membuat hukum sesuai dengan martabatnya.

Sehingga hubungan antara laki-laki dan perempuan diatur secara terhormat dan berdasarkan saling meridhai, dengan upacara ijab dan qabul sebagai lambang dari adanya rasa ridha-meridhai, dan dengan dihadiri para saksi yang menyaksikan kalau pasangan laki-laki dan perempuan itu telah saling terikat. Pernikahan menurut syari'at Islam setidak-tidaknya akan :

1. Membuat hubungan antara laki-laki dan perempuan menjadi terhormat dan saling meridhai.

2. Memberikan jalan yang paling sentosa sebagai naluri manusia, memelihara keturunan dengan baik dan menghindarkan kaum wanita dari penindasan kaum laki-laki.

3. Membuat pergaulan suami-isteri berada dalam naungan naluri keibuan dan kebapakan, sehingga akan melahirkan anak keturunan yang baik sebagai generasi penerus misi kekhalifahan.

Untuk menjaga kehormatan dan martabat manusia, Allah SWT mengadakan hukum sesuai dengan martabat tersebut. Allah menciptakan hubungan antara laki-laki dan perempuan dengan pernikahan sebagai jaminan kelestarianpopulasimanusiadimukabumi, sebagai motivasi dari tabiat dan syahwat manusia dan untuk menjaga kekekalan keturunan mereka. Dengan adanya dorongan syahwat seksual yang terpendam dalam diri laki-laki dan perempuan, mereka akan berfikir tentang pernikahan (Syeikh Muhammad Ali AshShabuny, 2001).

Upaya untuk melanjutkan proses regenerasi dalam Islam telah diatur melalui suatu cara yang lazim disebut dengan pernikahan. Pernikahan dalam
Islam merupakan pertalian yang sakral, tidak sekedar pertalian antara seorang laki-laki dan perempuan yang sekedar menghalalkan persetubuhan, Allah SWT menyebut pernikahan itu dengan "mitsaqon holizon"(janji yang erat), yaitu perjanjian antara suami istri untuk hidup bersama sedemikian kukuh, sehingga bila mereka dipisahkan di dunia oleh kematian, maka mereka yang taat melaksanakan pesan-pesanIlahi, masihakan digabung dan hidup bersama kelak di hari kemudian (M. Quraish Shihab, 2020). Hal tersebut dikarenakan pernikahan tidak sematamata sebagai hubungan atau kontrak keperdataan biasa, akan tetapi mempunyai nilai ibadah (AhmadRofiq, 1998).

Pernikahanmerupakansuatujalany angamatmuliauntukmengatur kehidupan rumah tangga serta keturunan dan saling mengenal antara satu dengan yang lain, sehingga akanmembuka jalan untuk saling tolong- menolong (Sulaiman Rasjid, 1992).

Selainitu, pernikahan merupakan institusi yang sangat penting dalam kehidupan bermasyarakat sebagai sarana awal untuk mewujudkan sebuah tatanan masyarakat dan keluarga sebagai pilar penyokong kehidupan bermasyarakat (Abdul Jalil, 2000). Penciptaan manusia sebagai hamba (agar beribadah kepada Allah SWT) ini mengemban misi untuk meramaikan bumi dengan aturan-aturan yang ditetapkan oleh Allah SWT sendiri.

Pernikahan adalah sebuah proses awal dimana seseorang akan melanjutkan kehidupan bersama pasangannya dalam ikatan suatu rumah tangga, untuk menanamkan fondasi bagi terciptanya keluarga yang sakinah, mawad- dah, warohmah (Taufiq, Justisia, 2004).

Didalam pernikahan disyaratkan adanya wali yang bertanggungjawab dalam pernikahan seorang gadis, sebab ia masih buta dan masih muda. Ia belum mengetahui arti hidup dan pergaulan dalam hidup itu. Maka dianggap nikah itu 
hanya jalankeluarga dari keadaan yang dihadapi dan rasa hidup mandiri.

Wali disyaratkan dari kalangan keluarga pria yang berdekatan darah dengan sang ayah siwanita. Akan tetapi jika tidak ada wali yang demikian ini, maka boleh berpindah kepada wali Hakim.

\section{METODE}

Jenis penelitian yang digunakan dalam penulisan Tesis ini adalah penelitian kepustakaan (library research). Penelitian ini dilakukan dengan mengumpulkan data tentang Penetapan Wali Adhol Dalam Pernikahan (Studi Komparasi Antara Hukum Islam Dan KHI) dari buku, artikel, majalah, surat kabar, atau sumber kepustakaan lainnya, yang kemudian diambil kesimpulan berdasarkan data tersebut.

\section{HASIL DAN PEMBAHASAN Wali Adhol}

Yang dikatakan wali adalah orang paling dekat dengan si wanita. Dan orang yang berhak menikahkan wanita adalah ayahnya lalu kakeknya dan seterusnya keatas. Boleh juga anaknya dan cucunya, kemudian saudara seayah seibu, kemudian saudara seayah, kemudian paman (MuhammadKhotib alSarbani, tt). Wali secara umum adalah seseorang yang karena kedudukannya berwenang untuk bertindak terhadap dan atas namaorang lain. Sedangkan wali dalam pernikahan adalah seorang yang bertindak atas nama mempelai perempuan dalam suatu akad nikah (Amir Syarifuddin, 2006). Dalam kamus besar Bahasa Indonesia, Wali diartikan sebagai pengasuh pengantin perempuan ketika menikah, yaitu orang yang melakukan janji nikah dengan lakilaki (TimPenyusun Kamus, 1989).

Wali $\begin{gathered}\text { Sedangkan } \\ \text { yang }\end{gathered}$ engali Adhol adalah
menolak. Maksudnya adalah seorang Wali yang enggan atau menolak menjadi
Wali dalam pernikahan anak perempuannya dengan seorang laki-laki yang sudah menjadi pilihan anaknya (Ahrun Khoeruddin, 1999).

Apabila seorang perempuan telah meminta kepada Walinya untuk dinikahkan dengan laki-laki seimbang (sekufu) dan Walinya berkeberatan dengan tidak ada alasan, maka Hakim berhak menikah kannya setelah ternyata bahwa keduanya sekufu dan setelah memberi nasehat kepada Wali agar mencabut keberatannya itu (Sulaiman Rasyid, 2004).

\section{Hukum Islam}

Istilah hukum Islam berasal dari dua kata dasar, yaitu 'hukum' dan 'Islam'. Dalam Kamus Besar Bahasa Indonesia kata 'hukum' diartikan dengan :1) peraturan atau adat yang secara resmi dianggap mengikat ;2) undang-undang, peraturan, dsb untuk mengatur pergaulan hidup masyarakat; 3) patokan (kaidah, ketentuan) mengenai peristiwa tertentu; dan 4) keputusan (pertimbangan) yang ditetapkan oleh hakim (dipengadilan) atau vonis.

Secara sederhana hukum dapat dipahami sebagai peraturan-peraturan atau norma-norma yang mengatur tingkah laku manusia dalam suatu masyarakat, baik peraturan atau norma itu berupa kenyataan yang tumbuh dan berkembang dalam masyarakat mau pun peraturan atau norma yang dibuat dengan cara tertentu dan ditegakkan oleh penguasa. Kata yang kedua, yaitu'Islam', oleh Mahmud Syaltout didefinisikan sebagaiagama Allah yang diamanatkan kepadaNabi Muhammad SAW, untuk mengajarkan dasar-dasar dan syariatnya dan juga mendakwahkannya kepada semua manusia serta mengajak mereka untuk memeluknya.

Dengan pengertian yang sederhana, Islam berarti agama Allah yang dibawa oleh Nabi Muhammad saw lalu disampaikan kepada umat manusia untuk mencapai kesejahteraan hidupnya 
baik didunia mau pun diakhirat kelak. Dari gabungan dua kata 'hukum' dan 'Islam' tersebut muncul istilah hukum Islam. Dengan memahami arti dari kedua kata yang ada dalam istilah hukum Islam ini, dapatlah dipahami bahwa hukum Islam merupakan seperangkat norma atau peraturan yang bersumber dari AllahSWT dan Nabi Muhammad SAW untuk mengatur tingkah laku manusia ditengah- tengah masyarakatnya. Dengan kalimat yang lebih singkat, hukum Islam dapat diartikan sebagai hukum yang bersumber dari ajaran Islam.

KHI

Secara etimologis, "Kompilasi" berartikumpulan/ himpunan yang tersusun secarateratur. Term Kompilasi diambil dari compilation (Inggris) atau compilatie (Balanda) yang diambil dari kata compilare, artinya mengumpulkan bersama-sama seperti mengumpulkan peraturan-peraturan yang tersebar berserakan dimana-mana. Istilah ini kemudian dipergunakan dalam bahasa Indonesia“ Kompilasi” sebagai terjemahan langsung (Abdurrahman, 1992). Dalam kamus Webster's Word University, Kompilasi (compile) didefenisikan: "Mengumpulkan bahanbahan yang tersedia ke dalam bentuk teratur, seperti dalam bentuk sebuah buku, mengumpulkan berbagai macam data (Lewis Mulfered Adms dkk, 19965).

Konsep Wali 'Adhal Dalam Pernikahan dan dasar hukumnya dalam pernikahan Menurut Hukum Islam

\section{Wali 'Adhal Dalam Pernikahan Menurut Hukum Islam}

Dalam ajaran Islam orang tua tidak boleh memaksa mengawinkan anak putrinya yang sudah dewasa dengan laki-laki yang tidak disukainya (Ghazali Mukri, 200). Orang tua berkewajiban meminta pendapat anak putrinya mengenai laki-laki yang akan dijodohkan, apakah ia mau menerima laki-laki itu atau menolak nya. Apabila anak perempuannya itu janda, maka ia harus menyam paikan persetujuannya secara terus terang. Tapi jika anak perempuannya gadis, maka diamnya adalah tanda setuju karena diakuinya perasaan malu. Jika ia mengatakan "tidak" maka orang tua tidak berwenang untuk memaksakan ia nikah dengan laki-laki yang tidak disukai. Kerena dengan orang tua memaksa anak perempuannya nikah dengan laki-laki yang tidak disukai bisa mengakibatkan hal-hal yang tidak diinginkan, bisa saja anak perempuannya kabur dari rumahnya dan melakukan pernikahan yang tidak sesuai dengan prosedur hukum, bahkan anak tersebut bisa bunuh diri karena akan dijodohkan dengan lakilaki yang tidak disukainya.

Pada masa sekarang memang banyak terjadi perselisihan antara orang tua dengan anak perempuannya mengenai hal pernikahan. Oleh sebab karena terjadi perselisihan antara orang tua dengan anak perempuannya kemungkinan besar orang tua tidak bersedia menikahkan anak perempuannya atau enggan ('Adhal) menjadi wali bagi anak perempuannya.

Salah satu prinsip pernikahan dalam Islam adalah persetujuan masing-masing pihak dan didasarkan atas perasaan sukarela. Hal ini sebagaimana Nabi bersabda:

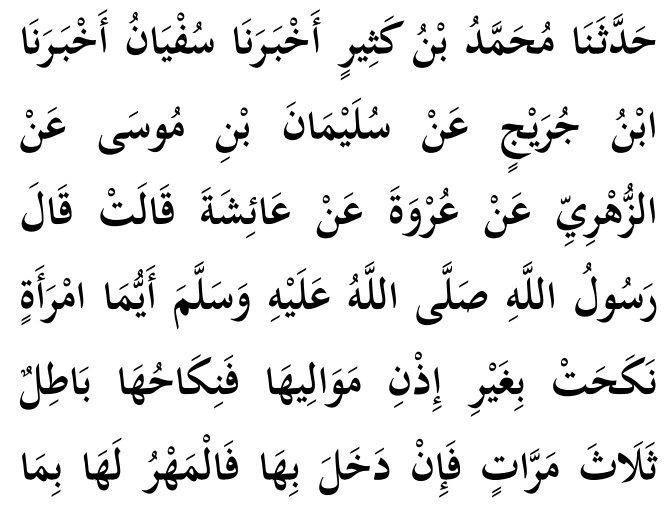




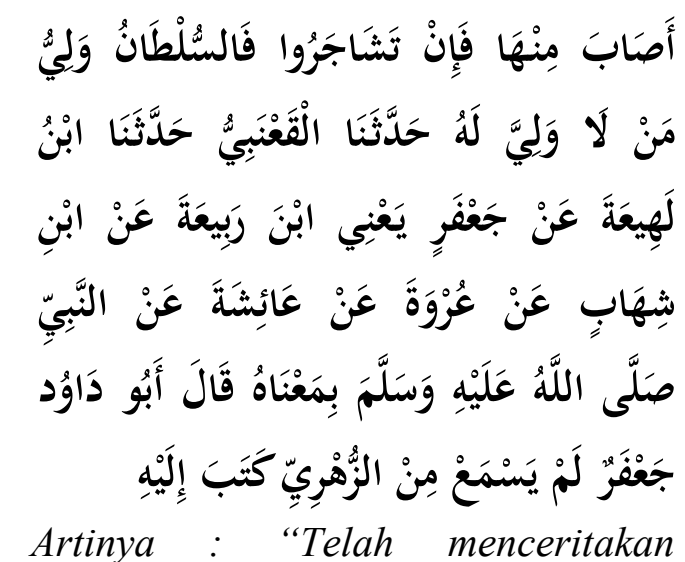

kepada kami Muhammad bin Katsir, telah mengabarkan kepada kami Sufyan, telah mengabarkan kepada kami Ibnu Juraij, dari Sulaiman bin Musa dari Az Zuhri dari Urwah, dari Aisyah, ia berkata; Rasulullah shallallahu 'alaihi wasallam bersabda: "Setiap wanita yang menikah tanpa seizin walinya, maka pernikahannya adalah batal." Beliau mengucapkannya sebanyak tiga kali. Apabila ia tleah mencampurinya maka baginya mahar karena apa yang ia peroleh darinya, kemudian apabila mereka berselisih maka penguasa adalah wali bagi orang yang tidak memiliki wali. Telah menceritakan kepada kami Al Qa'nabi, telah menceritakan kepada kami Ibnu Luhai'ah, dari Ja'far bin Rabi'ah, dari Ibnu Syihab dari 'Urwah dari Aisyah dari Nabi shallallahu 'alaihi wasallam semakna dengannya. Abu Daud berkata; jal'far tidak mendengar dari Az Zuhri, ia menulis surat kepadanya" (HR. Abu Daud : 1784) (Abu Dawud Sulaiman bin Al-Asy'ats bin Ishaq bin Basyir Al-Azdiy AsSijistani, $t \mathrm{t}$ )

\section{a. Pendapat Mazhab Hanafi}

Di dalam mazhab Hanafiah juga telah di dapati keterangan mengenai wali 'Adhaltersebut, namun demikian keterangan yang dapat di ungkapkan di sini adalah keterangan dari para ulama mazhab tersebut. Sebagaimana di ungkapkan oleh Abdurrahman al Jaziri melalui kitabnya, bahwa menurut ulama madzhab Hanafi adalah wali aqrab yang melakukan pencegahan terhadap maulanya dari kawin dengan pasangan yang telah sekufu berikut dengan membayar mahar mitsil, maka jalan penyelesaianya di sebut sama halnya dengan penyelesaian atas wali yang ghaib yang sulit di temukan dan di datangkan. Demikianlah itu perwaliannya tidak pindah kepada wali hakim, selagi masih ada wali yang lain yaitu wali $a b$ ' $a d$.

$$
\text { Lebih lanjut Syekh }
$$

Abdurrahman al-Jaziri mengutip penjelasan Imam Abu Hanafiah, mengenai wali'Adhal tersebut sebagaimana penjelasan nya sebagai berikut:

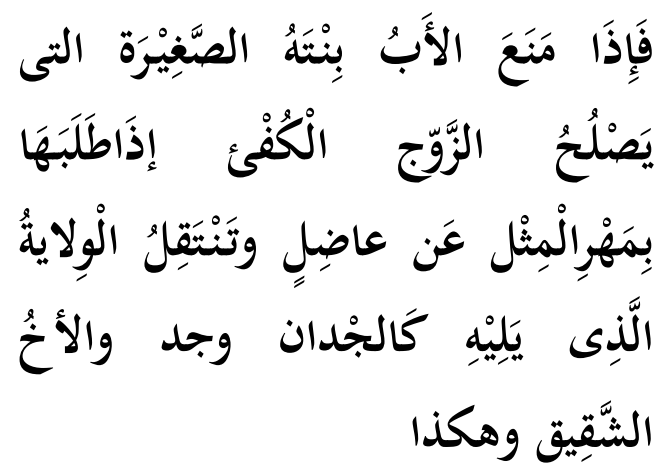

Artinya: “Apabila ada seorang bapak mencegah (melarang) anak perempuannya yang masih kecil, dan ia telah patut untuk di kawinkan, lagi pula pasangan calon suami telah sekufu dan dengan membayar mahar mitsil, maka dengan demikian wali yang bersangkutan (bapak) adalah 'Adhaldan dengan demikian pula perwalian menjadi pindah kepada wali berikutnya, seperti kepada kakek, jika ada dan kalau kakek tidak ada maka kepada saudara sekandung dan seterusnya." (Abdurrahmān al-Jazīin̄, tt)

\section{b. Pendapat Mazhab Maliki}

Dalam Mazhab Maliki, ada kecendrungan sama dalam 


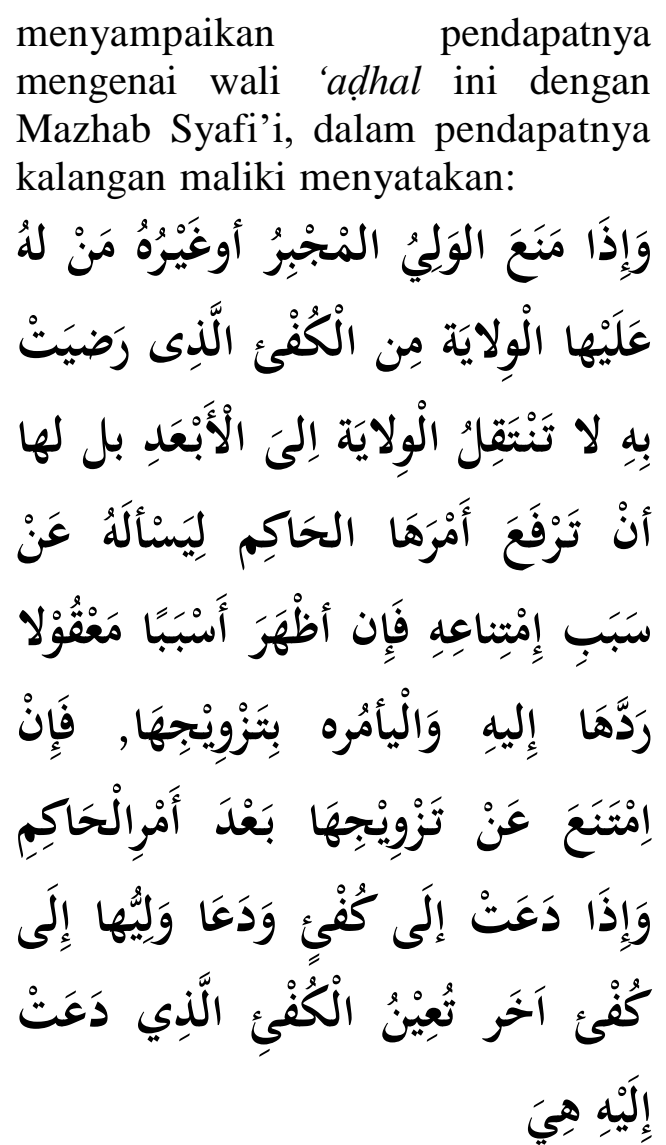

Artinya: "Tatkala ada seorang wali baik itu mujbir atau bukan, menghalangi maulanya untuk kawin dengan pasangan yang sekufu lagi pula si maula rela terhadapnya, maka perwalian tidak pindah pada wali yang jauh (wali ab'ad) akan tetapi berhak bagi si maulanya untuk melaporkan perkaranya kepada hakim, dengan maksud untuk mempertanyakan kepada si wali mengenai sebab sebab itu dan masuk akal, maka hakim menyerahkan urusan maula tersebut kepadanya, akan tetapi kalau tidak, hakim memerin tahkan pada si wali membangkang untuk mengawin kannya setelah di perintahkan hakim, maka hakim bertindak untuk mengawinkannya." (Abdurraḥmān al-Jazīrī, tt)

Lebih dari itu, dalam keterangan salah seorang pendukung dari mazhab ini yaitu Ibnu Rusydi juga di dapati keterangan yang sama dengan apa yang telah di sebutkan di muka yakni mengenai penentuan problema berikut upaya penyelesai nya yang sama-sama melalui seorang hakim, akan tetapi dalam Ibnu Rusydi tersebut menangani pergantian wali tidaklah dilakukan oleh hakim, akan tetapi oleh wali berikutnya selain wali aqrab, hal ini tampak pada keterangan:

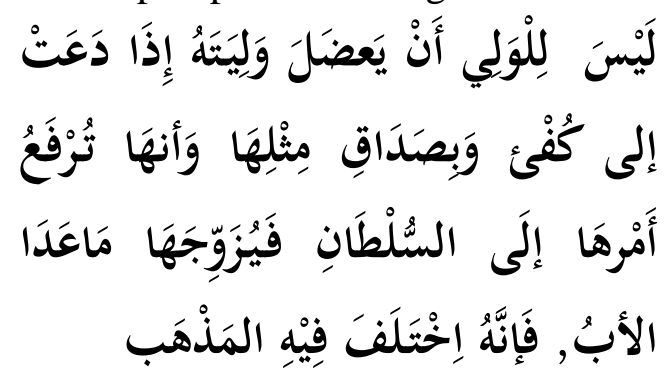

Artinya: "Bahwa bagi wali tidak berhak untuk menghalangi anak yang di walinya (dari kawin), manakala ia menghendaki pasangan yang telah sekufu dan dengan mahar mitsilnya. Maka bila si wali mecegah hendaknya bagi perempuan yang di wali melaporkan perkaranya pada hakim, dan kemudian untuk perkawinannya di lakukan oleh wali berikutnya selain bapa (aqrab)." (Ibn Rusyd, tt)

Pendapat yang di sampaikan oleh Ibnu Rusydi, menurut keterangan di dasarkan petunjuk hadits yang diriwayatkan oleh diriwayatkan oleh Aisyah R.A yang di antaranya menyebutkan:

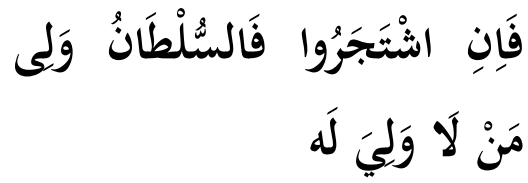

Artinya: "Maka apabila terjadi sengketa, hakim adalah wali bagi seorang yang baginya tidak punya wali." (HR. Abu Daud, At-Tirmidzi dan Ibnu Majah) (Al-Tirmīzī, tt)

Dengan dapat diperoleh kesimpulan umum, bahwa dalam mazhab maliki bagaimana problema dan penyelesaian wali 'adhal tentu 
melihat seorang hakim, dan bagi hakim berkewajiban menggantikan nya sebagai jalan menuju jalan penyelasiannya bila dalam wali yang bersangkutan tetap dalam sikap 'adal-Nya. Namun demikian ada di antara ulama dari mazhab ini yang berpendapat lain, yakni melalui wali kerabat yang lain selain wali aqrab, guna mencapai penyelesainya.

\section{c. Pendapat Mazhab Syafi'i}

Pembahasan mengenai proble ma wali 'Adhal berikut penyelesaian nya di dalam madzhab Syafi'i kedua sama-sama melibatkan seorang penguasa (Hakim) sebagai pengendalinya. Adapun mengenai keterlibatan penguasa atau hakim selaku pengendali kedua hal tersebut maksudnya adalah dialah yang berwenang untuk memproses dan mengusut permasalahan wali yang berkondisi 'Adhal tersebut, berikut mengusahakan dengan upaya apa yang mengantisipasi dan penyele saian munculnya permasala han tersebut, hal ini di lakukan penguasa atau hakim tentunya setelah ada laporan pengajuan dari maula wali 'Adhal tersebut sebagai pihak yang di rugikan. Mengenai keterlibatan seorang hakim terhadap wali 'Adhal tampak pada ulasan seorang ulama dari mazhab Syafi'i, yakni Imam Jalaluddin al Mahalli yang antara lain menerangkan:

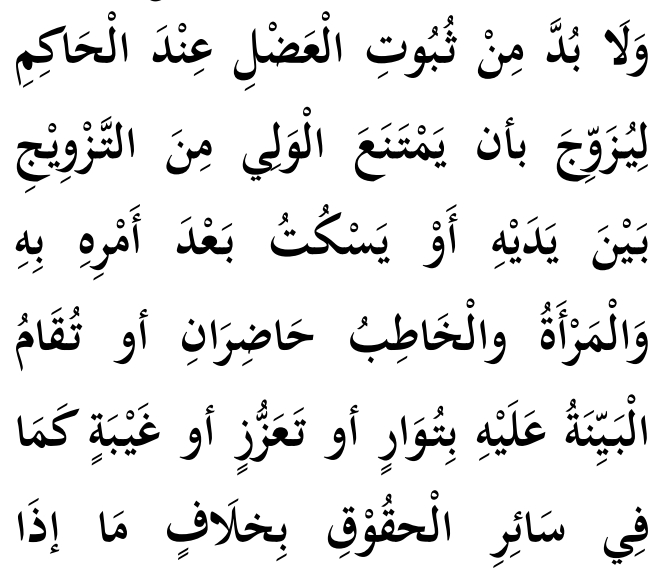

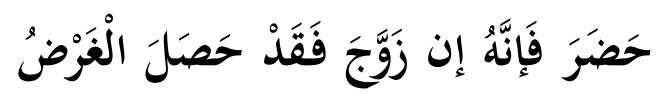

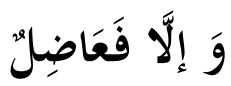

Artinya: "Diharuskan dalam mencari kepastian bahwa seorang wali itu 'Adhaladalah di muka hakim setelah di perintah dan nyata-nyata menolak untuk melangsungkan perkawinan, sedangkan perempuan yang menjadi maulanya berikut laki-laki yang melamar juga hadir, atau juga ia di datangkan saksi untuk memperkuat atau menyem bunyikannya (ini bila ia tidak hadir), dan setelah di hadapkan hakim, lalu si wali bersedia mengawinkannya. Tercapailah tujuan untuk mengantisipasi wali 'Adhalakan tetapi sebaliknya bila ia tidak bersedia mengawinkan maka nyatalah ia sebagai wali 'Adhal (Jalāluddīn bin Muhammad bin Aḥmad Al Maḥallī, 1974)

Demikian keterlibatan seorang hakim dalam menghadapi wali 'Adhal berikut upaya awal untuk mengansitipasinya, namun demikian bila dipahami bahwa upaya tersebut akan membawa hasil manakala si wali kembali dari 'Adhal (bertaubat), yaitu bersedianya untuk melangsungkan akad perkawinan dalam kaitan ini, pernah di ulas oleh seorang ulama Mazhab Syafi'i juga, yaitu al Qalyubi dalam keterangan menjelaskan:

Taubatnya seorang wali yang 'adal itu terwujud dengan bersediannya untuk mengawinkan, dan dengan itu pula kembali perwaliannya, dan andai kata si hakim yang melangsungkan perkawinan karena ke 'aḍal-nya wali, lalu si wali mengaku bahwa dirinya telah menarik kembali dari 'aḍalnya dan akan melangsungkan perkawinannya 
sebelum di langsungkan oleh hakim, hal tersebut yakni pengakuan kembali wali, tidak bias di terima kembali kecuali dengan saksi-saksi." (Jalāluddīn bin Muhammad bin Ahmad Al Maḥallī, 1974).

Dari ulasan di atas semakin terang, bahwa langkah awal yang di sajikan ulama fiqih dalam menghadapi wali 'Adhal tersebut. Dalam proses penyelesaian atas sikap 'adal-Nya, Ma'qil tidak keberatan dan menarik kembali taubat dari 'adal-nya. hal itu di lakukan di hadapan dan setelah ada fatwa yang bernada melarang dari Nabi SAW selaku hakimnya atas perbuatannya yang tercela tersebut, pernyataan yang menggam barkan taubatnya Ma'qil secara terang di muat dalam suatu riwayat hadits yang di keluarkan oleh Imam Bukhari dan Imam Abu Qudamah mengutip sebagaimana tersebut:

فَقُقْتُ الْلانَ أَنْ أَفْعَلَ يا رَسْوُلْ اللهِ قَاَلَ

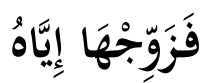

Artinya: Lalu aku katakan, sekarang akan aku kerjakan wahai Rosulullah (sebagai pernyataan taubatku) dan kata perawi, lalu dia kawinkan maulanya dengal bakal suaminya (Al-Imām Syamsuddīn Abī Faraj Abdurrahmān Ibnu Qudamah Almunqaddasi,tt)."

Demikian bila terjadi pembangkangan dari wali 'Adhal ini, artinya cara awal yang ditempuh hakim belum dapat diantisipasi sikap ke'adalannya wali tersebut. Menurut Madzhab ini, maka hakim yang telah mengawinkan atas diri maula dari wali 'Adhal tersebut atau mewakilkan kepada orang lain untuk mengawinkan. Mengenai hal ini, pernah dijelaskan langsung oleh Imam As Syafi'i melalui kitabnya Al-Umm yang antara lain memberi keterangan:

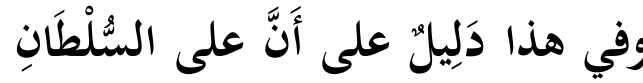

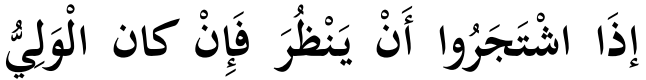
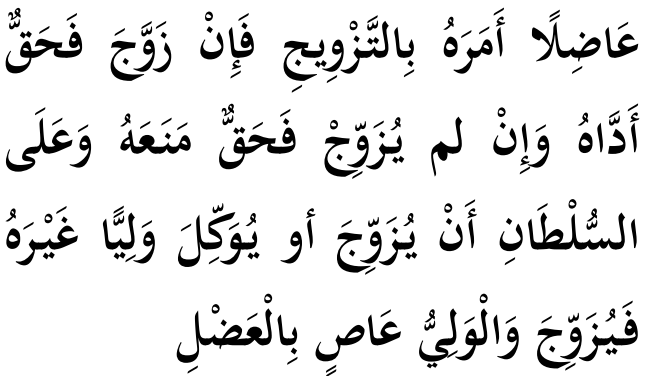

Artinya: "Bila para wali terjadi sengketa, hendaknya seorang hakim memperhatikan, bahwa kalau saja si wali itu seorang wali yang 'adhal, maka diperintahkan untuk sanggup mengawinkan, maka apabila wali mengawinkan, habislah masalahnya, tetapi apabila wali tidak mau mengawinkan, maka teranglah pencegahan atau pembangkangannya, dan kewajiban bagi wali hakim untuk mengawinkan atau mewakilkannya kepada orang (wali) lain untuk mengawinkan."( Al-Imām Abī Abdillah Muhammad bin Idrīs Al-Syafi' '̄', 1983)

Dalam keterangan yang lain Imam Syafi'i menjelaskan bahwa perpindahan wali pergantian wali atas diri wali 'Adhal kepada hakim. Ini terjadi manakala yang'Adhal itu dari wali dekat aqrab. Sedang wali yang lain yaitu wali yang $a b$ 'ad tidak bisa mengganti pengganti, dengan kata lain ditangguhkan karena hakim sajalah yang berwenang untuk penggantinya. Lebih jauh dijelaskan oleh beliau melalui keterangan:

"Tatkala seorang wali itu hadir, lalu dia membangkang dan melang sungkan perkawinan, maka tidak bisa melangsungkan perkawinan maulanya wali yang lain dari golongan kerabat, 
tetapi hakim sajalah yang berwenang (berhak) mengawinkannya. Dan ini setelah ada laporan dan pembuktian oleh hakim. Di antaranya hakim berhak mempertanyakan mengenai wali yang 'Adhal tersebut, kalau saja ghaib, maka beralih mengenai pihak yang melamar. Maka, kalau saja hakim telah menerima laporannya dan telah membenarkan laporan tersebut maka hakim memerintahkan untuk mendatangkan wali yang lebih dekat wali aqrab dan kerabat lain dari keluarganya. Lalu hakim mempertanyakan : apakah kamu sekalian berkeberatan sekali untuk mengawinkan?, kalau saja mereka menjawab berkeberatan, maka hakim harus memandang kalau saja bagi si pelamar dipandang telah sekufu, sedangkan bagi si perempuan telah rela untuk menerimanya, maka hakim memerintahkan kepada mereka untuk mengawinkannya. Dan kalaupun hakim tidak memerintahkan mereka terlebih dahulu, hakimpun berkewenangan untuk mengawinkannya, karena kalau saja terjadi ada seorang wali yang hadir lalu ia membangkang untuk mengawinkan maulanya dengan pasangan yang disukainya, maka hakim juga akan mengawinkannya dengan pasanganyang disukai tadi (AlImām Abī Abdillah Muhammad bin Idrīs Al-Syafi' '̄, 1983)."

$$
\text { Adapun mengenai }
$$

perwakilan seorang hakim, juga telah diterangkan beliau melalui keterangannya:

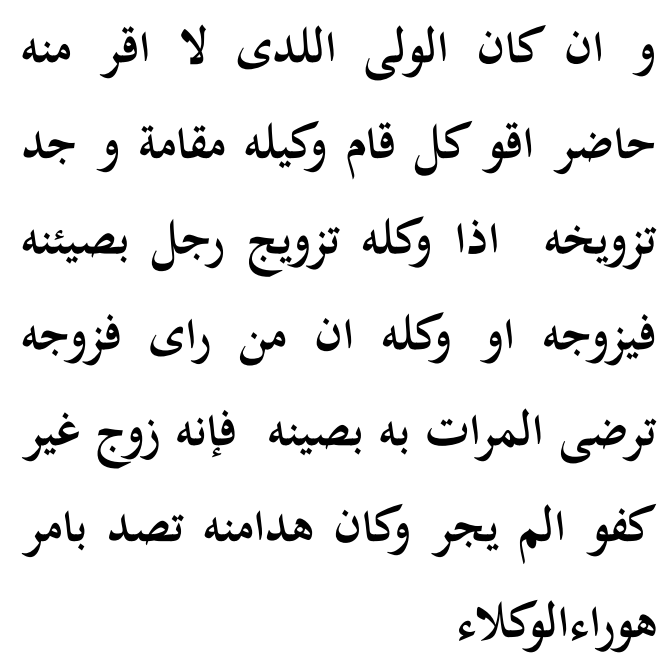

Artinya: "Kalau wali yang bukan aqrab artinya wali ab'ad itu hadir, lalu diangkatnya menjadi wakil oleh hakim, maka dengan demikian perwakilannya menduduki kedudu kan hakim, dan boleh mengawin kan. Hal tersebut diperbolehkan mengingat diperboleh kannya menjadi wali untuk mengawinkan orang laki-laki yang telah tertentu adanya, atau menjadi wakil untuk mengawinkan atau mengawinkan dengan seorang yang dia lihat, dan betul telah mengawinkan dengan seseorang yang telah sekufu dan si perempuan telah mene rima rela terhadap seseorang tadi. Akan tetapi bila seseorang tadi tidak sekufu maka perkawinannya tidak boleh dilangsungkan, karena dengan tidak sekufu itu menjadi tertolak perkawinannya begitu pula perwakilannya kepada para wakil, itu juga tertolak."

Namun demikian ada kecendrungan dari kalangan mazhab Syafi'i, bahwa untuk menyelesaikan wali 'Adhal tidak saja terkuasai oleh hakim sebagai pihak yang berkewenangan untuk menggantikannya, akan tetapi juga wali yang jauh wali ab'ad pun berkewenangan untuk menggan tikannya, dengan syarat ke 'adalnya yang di lakukan wali aqrab 
telah berkali-kali, yaitu tiga kali berturut- turut atau lebih, mengenai hal ini di ungkapkan oleh seorang ulama fiqih masa kini, yakni Syeh Abdurahman al Jaziri dalam kitabnya Kitabul fiqih 'Alal Madzahibin Arba'ah mengungkapkan, kalangan mazhab Syafi'i berpendapat:
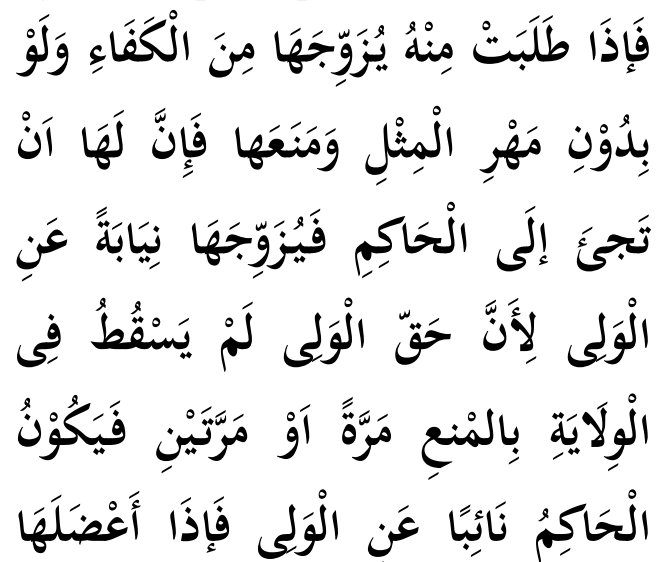

ثَلَاثَ مَرَّاتٍ فَأُكْثَْْ فَإنَّهُ يَكُوْنُ بِذَالكِكَ
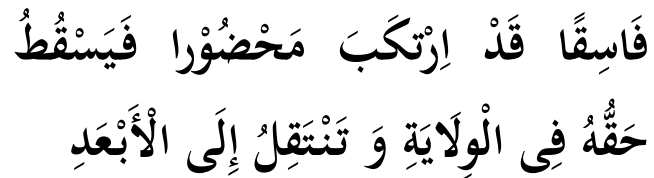

Artinya: "Bahwa apabila seorang wali melakukan pencegahan terhadap perempuan di walinya dari perkawinan, sedangkan dia menghen daki untuk di langsungkan perkawinan tersebut, mengingat pasa ngannya yang telah sekufunya dan walaupun dengan mahar kurang dari mahar mitsil, dari itu ia berhak untuk melaporkan perkaranya kepada hakim, kemudian hakim mengawin kannya sebagai penggantinya dari wali yang bersangkutan karena hak bagi si wali tersebut belum gugur lantaran pencegahannya yang di lakukan baru sekali atau dua kali saja, maka hakim lah yang menggantikannya. Akan tetapi pencegahannya itu sampai berkalikali (tiga kali atau lebih), maka ialah yang menjadi fasiq dan di nyatakan telah melakukan perbuatan terlarang dengan demikian gugurlah haknya dan pindahlah perwalian kepada wali lain yaitu wali ab'ad."

Demikianlah penjelasan dari mazhab Syafi'i berikut para ulama' pengikutnya mengenai problema wali 'Adhal berikut upaya penyelesaiaan nya, dan dari penjelasan tadi atas, dapat di peroleh kesimpulan bahwa dalam mazhab Syafi'i wali 'Adhal akan tampak dan nyata sebagai suatu problema dalam perwalian, manakala telah di hadapkan dan di buktikan oleh hakim yang menanganinya mengenai ke 'adal- Nya, hakim berkewajiban untuk mengupayakan agar perkawinan maulanya bisa berlangsung pertama dengan intruksi untuk mencabut ke adal-Nya yaitu dengan sanggup melangsungkan perkawinannya, dan kalau saja dia masih mecegah atau membangkang maka kewajiban bagi hakim untuk menempuh cara kedua yaitu penggatian wali.

\section{d. Pendapat Mazhab Hanbali}

Di dalam Mazhab Hanbali di ceritakan tentang Ahmad bin Hanbal bahwa beliau pernah memberikan penjelasan mengenai wali 'adal. Di satu riwayat, bahwa wali yang 'Adhal terutama yang 'Adhal itu adalah wali aqrab, maka dengan demikian perwalian berpindah kepada wali $a b^{\prime} a d$, sedang di sisi yang lain menjelaskan bahwa perwalian menjadi pindah kepada hakim (Al-Imām Syamsuddīn Abī Faraj Abdurraḥmān Ibnu Qudamah Almunqaddasi, $t \mathrm{t}$ ).

Namun dengan demikian, wali 'Adhal berikut upaya penyelesaiannya telah di tanggapi di bahas oleh kalangan mazhab Hanabilah ini, walau tetap tidak melepaskan kemungkinan perbedaan pendapat di antara mereka. Walau demikian Syeh Abdurrahman al Jaziri 
sebagaimana ada dalam keterangannya, yakni hampir sama dengan pendapat hanabilah mengenai wali 'Adhalini, pendapat beliau:

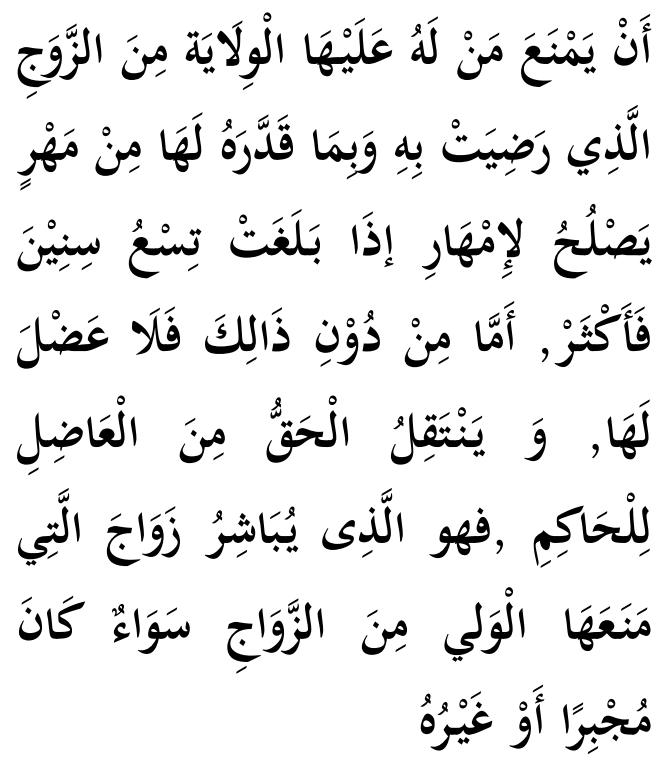

Artinya: "Apabila ada seseorang yang mempunyai hak perwalian (wali) mencegah maulanya dari kawin dengan calon suami yang telah ia cintai, dan dengan memberi mahar, dan dia telah mencapai umur sembilan tahun bahkan lebih (ia telah baligh), sikap wali tersebut tidaklah sebagai ke adaNya wali terhadap maulanya dan bila wali itu 'Adhalmaka perwalian berpindah kepada hakim, karena dialah yang berkewenangan untuk mengawinkan atas diri maula yang di wali mencegah dari kawin, baik itu wali mujbir maupun bukan mujbir

Demikian penjelasan ulasan dari mazhab Hanabilah mengenai wali 'Adhalberikut upaya penyelesa iannya. Kiranya dari keterangan tersebut dapat di peroleh kesimpulan bahwa dalam mazhab Hanbali dalam hal ini ulamanya cendrung dalam proses dan penyelesaian wali 'Adhal dengan melalui seorang hakim, dan hakim pula yang tampil sebagai penggantinya manakala ia wali yang bersangkutan tetapi dalam ke'adalnya. Namun demikian ada di antara mereka yang berpendapat lain, yakni penyelesaian wali 'Adhal dengan melalui wali kerabat yang lain walaupun wali yang jauh sekalipun, baru kemudian pindah ke hakim setelah mereka tidak bisa di harapkan untuk tampil sebagai wali.

\section{Wali 'Adhal Dalam Pernikahan Menurut KHI}

Permasalahan wali nikah adalah pembahasan yang paling penting dalam Kompilasi Hukum Islam. Pada Pasal 19 KHI menegaskan sbahwa wali nikah dalam perkawinan merupakan rukun yang harus dipenuhi bagi calon mempelai wanita yang bertindak untuk menikahkannya. ${ }^{56}$ Ini adalah rukun/syarat menurut mayoritas ulama kecuali mazhab Hanafi, dan menurut mayoritas ulama, pernikahan hanya akan sah bila ada wali, berdasarkan ( لاف ضعتلو هن نأ ينكحن (اوز أهجن. Menurut Imam al-Syafi'i, ayat inilah ayat yang paling jelas dalam perlunya wali (Jalâl al-Dîn alMahallî, tt). Sekiranya wali tidak perlu, maka larangan ke atas wali yang menghalang pernikahan seperti ayat di atas tidak akan memberi sebarang makna. Ada juga hadis Rasulullah SAW:

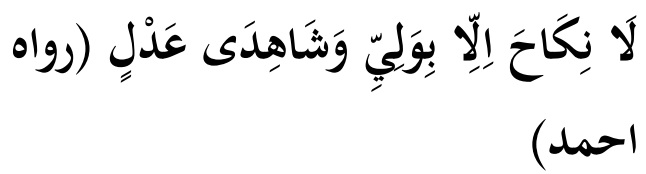

Oleh karena itu, KHI secara tegas mewajibkan adanya wali dalam pernikahan. Selanjutnya, KHI menetapkan pada Pasal 20 sebagai berikut:

1. Yang bertindak sebagai wali nikah ialah seorang laki-laki yang memenuhi syarat hukum Islam yakni muslim, aqil dan baligh,

2. Wali nikah terdiri dari : (a) Wali 
nasab, dan (b) Wali hakim. Pasal 20 angka (1) ini telah ditetapkan di dalam fiqh, lebih-lebih lagi di dalam mazhab Syafi'i. Menurut Imam al-Bâjûrî, syarat yang harus dipenuhi bagi seorang wali adalah 1. Islam, 2. Baligh, 3. Berakal, 4. Merdeka, 5. Lelaki, 6. Adil (tidak fasik). Dari uraian Imam alBâjûrî ini ada dua yang tidak dicantumkan KHI; yaitu merdeka dan adil. Merdeka tidak dicantumkan karena memandang status merdeka sudah pasti wujud dan tidak perlu diqayyidkan karena memandang sekarang sudah tidak ada perham baan. Sedangakan status adil tidak dicantumkan karena berpega ngan pada pendapat kedua di dalam mazhab Syafi'i, bahwa wali fasik tetap dapat menjadi wali nikah (Kementerian Agama RI, 2010).

Dalam Pasal 20 angka (2) pula ditetapkan pembagian wali menjadi dua, yaitu wali nasab dan wali hakim. Dalam hal ini, pada dasarnya senada dengan kitab-kitab fiqh. Di dalam kitab Syarqâwî alâ al-Tahrîr, wali dibagi menjadi 4 yaitu kebapakan (bapak, datuk, ke atas), yang mendapat waris 'ashabah dari nasab, sifat kekuasaan perhambaan (الولاء), dan wilayah kesultanan atau kehakiman (Imam alSyarqâwî,tt). Kalau ditinjau dari pernyataan ini, dapat disimpulkan menjadi 3, yaitu dari segi nasab (yang pertama kebapakan dan waris 'ashabah), dari segi kekuasaan perhambaan (الولاء), dan wilayah kesultanan atau kehakiman. dalam konteks Indonesia, yang ada adalah dari segi nasab dan wilayah kehakiman, maka sesuailah dengan ketentuan Pasal 20 angka (2). Untuk mengatur siapa saja yang menjadi wali bagi seorang perempuan bagi ketentuan Pasal 20 angka (2) huruf (a), maka Pasal 21 KHI mengatur sebagai berikut:

a. Wali nasab terdiri dari empat kelompok dalam urutan kedudukan, kelompok yang satu didahulukan dan kelompok yang lain sesuai erat tidaknya susunan kekerabatan dengan calon mempelai wanita. Pertama, kelompok kerabat laki-laki garis lurus ke atas yakni ayah, kakek dari pihak ayah dan seterusnya. Kedua, kelompok kerabat saudara laki-laki kandung atau saudara laki-laki seayah, dan keturunan laki-laki mereka. Ketiga, kelompok kerabat paman, yakni saudara laki-laki kandung ayah, saudara seayah dan keturunan laki-laki mereka. Keempat, kelompok saudara laki-laki kandung kakek, saudara laki-laki seayah dan keturunan laki-laki mereka.

b. Apabila dalam satu kelompok wali nikah terdapat beberapa orang yang sama-sama berhak menjadi wali, maka yang paling berhak menjadi wali ialah yang lebih dekat derajat kekerabatannya dengan calon mempelai wanita.

c. Ababila dalam satu kelompok sama derajat kekerabatan maka yang paling berhak menjadi wali nikah ialah karabat kandung dari kerabat yang se-ayah.

d. Apabila dalam satu kelompok, derajat kekerabatannya sama yakni sama-sama derajat kandung atau sama-sama dengan kerabat seayah, mereka sama-sama berhak menjadi wali nikah, dengan mengutamakan yang lebih tua dan memenuhi syarat-syarat wali.

Pada dasarnya, Pasal 21 ini semuanya sesuai dengan ketentuan yang terdapat di dalam figh mazhab Syafi'i. Hanya saja, sistematika KHI 
menggunakan pembagian kelompok agar mudah untuk difahami. Sedangkan sistematika yang biasa digunakan fiqh mazhab Syafi'i yang klasik adalah langsung memberikan urutan wali (تريتب الأولياء). Perlu untuk dicermati, KHI tetap konsisten sesuai dengan ketentuan fiqh Syafi'i di sini, karena pada angka (2), (3), dan (4) sudah ada klausul tertib sesuai urutan seperti dalam fiqh Syafi'i sendiri (Syaikh Abd alRahman al-Jazîrî, tt).

Selanjutnya Pasal 22 KHI pula mengantisipasi status wali nikah yang telah disebutkan dari segi kemampuan yang mereka miliki sebagai berikut: Apabila wali nikah yang paling berhak, urutannya tidak memenuhi syarat sebagai wali nikah atau oleh karena wali nikah itu menderita tuna wicara, tuna rungu atau sudah udzur, maka hak menjadi wali bergeser kepada wali nikah yang lain menurut derajat berikutnya.

Ketetapan perpindahan kewalian apabila wali yang lebih berhak tidak memenuhi syarat, itu adalah sesuatu yang sudah maklum seperti di dalam mazhab Syafi'i. Sedangkan ketentuan wali nikah yang menderita tuna wicara dan tuna rungu, atau sudah uzur tidak boleh menjadi wali dan kewaliannya berpindah pada orang di bawah derajatnya.

Ada beberapa faktor yang menyebabkan wali hakim dapat menjalan- kan fungsinya sebagai wali. Pada dasarnya wali hakim berfungsi sebagai pengganti, bukan sebagai wakil dari wali nasab, dalam keadaan hal-hal yang menyebabkan berpindahnya hak perwalian ke tangan wali hakim yang oleh hukum dan peraturan perundangundangan membenarkannya. Adapun sebab berpindahnya hak perwalian dari wali nasab ke wali hakim menurut Pasal 23 KHI, secara rinci dijelaskan dalam Peraturan Menteri Agama Republik Indonesia Nomor 30 tahun 2005 tentang Wali Hakim, mencakup sepuluh sebab, yaitu : (1) Sudah tidak ada garis wali nasab, (2) Wali Mafqud, (3) Wali sendiri yang hendak menikahi si terwali, (4) Wali ba id jauh (masalah qashar, sekurang-kurangnya $\quad 92 \frac{1}{2} \quad \mathrm{~km}$ ), (5)Wali sedang sakit pitam/ayan, (6) Wali tidak boleh dihubungi (dipenjara), (7)Wali dicabut haknya oleh negara, (8) Wali sedang melakukan ihram (haji dan umrah), (9) Wali tawâro (bersembunyi), dan (10)Wali adhal/mogok.

Faktor lain yang menyebab kan perpindahan wali dari nasab ke hakim adalah anak hasil di luar nikah (anak tidak sah). Menurut pasal 43 ayat (1) Undang-undang Nomor 1 Tahun 1974 menetapkan bahwa anak yang dilahirkan di luar pernikahan hanya mempnyai hubungan perdata dengan ibunya dan keluarga ibunya. KHI pasal 100 lebih menegaskan lagi bahwa anak tersebut tidak memiliki hubungan nasab dengan ayah biologisnya, hanya mempunyai hubungan nasab dengan ibunya dan keluarga ibunya. Karena tidak memiliki hubungan nasab dengan ayah biologisnya, maka wanita tersebut tidak memiliki seorang wali nasab pun, karena barisan wali nasab adalah dari garis ayah. Oleh sebab itu, maka perwaliannya berpindah kepada wali hakim.

Di dalam Kompilasi Hukum Islam proses peyelesaian terhadap wali yang 'Adhal dengan melalui seorang hakim, Sebagaimana dijelaskan dalam Kompilasi Hukum Islam pada Pasal 23:

(a) Wali hakim baru dapat bertindak sebagai wali nikah apabila wali nasab tidak ada atau tidak 
mungkin menghadirkannya atau tidak diketahui tempat tinggalnya atau gaib atau 'Adhal atau enggan.

(b) Dalam hal wali 'Adhal atau enggan maka wali hakim baru dapat bertindak sebagai wali nikah setelah ada putusan pengadilan Agama tentang wali tersebut.

Sedangkan dalam Peraturan Menteri Agama Peraturan Menteri Agama Nomor 30 Tahun 2005 ini menjelaskan tentang wali hakim bisa menggantikan wali nasab sebagai wali nikah, atau karena 'Adhal(menolak/ enggan), maka yang berhak menjadi wali nikah adalah wali hakim. Penyele saian wali 'Adhal dalam Peraturan Menteri Agama dijelaskan dalam Peraturan Menteri Agama Nomor 30 Tahun 2005 Pasal 2 ayat 1 sampai 2 terdapat aturan mengenai penetapan wali hakim, yaitu sebagai berikut:

a) Bagi calon mempelai wanita yang akan menikah di wilayah Indonesia atau di luar negri/di luar wilayah teritorial Indonesia, dan tidak mempuyai wali nasab yang berhak atau wali nasabnya tidak memenuhi syarat, atau mafqud, atu berhalangan, atau 'adal, maka pernikahannya dilangsungkan oleh wali hakim

b) Khusus untuk meyatakan 'adalNya wali sebagaimana tersebut pada ayat (1) Pasal ini ditetapkan dengan keputusan Pengadilan Agama/ Mahkamah Syar'iyah yang mewilayahi tempat tinggal calon mempelai wanita.

Selanjutnya dalam Pasal 3 Peraturan Menteri Agama Nomor 30 Tahun 2005 disebutkan:

a) Kepala Kantor Urusan Agama Kecamatan (KUA) dalam wilayah Kecamatan yang bersangkutan ditunjuk menjadi wali hakim untuk menikahkan mempelai wanita sebagaimana dimaksud dalam Pasal 2 ayat (1) Peraturan ini.

b) Apabila Kepala KUA Kecamatan sebagaimana dimaksud pada ayat (1) berhalangan atau tidak ada, maka Kepala Seksi yang membidangi tugas Urusan Agama Islam atas nama Kepala Kantor Urusan Departemen Agama Kabupaten/Kota diberi kuasa untuk atas nama Menteri Agama menunjuk salah satu Penghulu pada Kecamatan tersebut atau terdekat untuk sementara menjadi wali hakim dalam wilayahnya.

c) Bagi daerah terpencil atau sulit dijangkau oleh transportasi, maka Kepala Seksi yang membidangi tugas Urusan Agama Islam atas nama Kepala Departemen Agama menunjuk pembantu penghulu pada Kecamatn tersebut untuk sementara menjadi wali hakim dalam wilayahnya.

Penetapan wali adhal diatur dalam Peraturan Menteri Agama No.2 Tahun 1987 Pasal 2 ayat (2) dan (3). Adapun sebab-sebab terjadinya wali hakim berdasarkan Kompilasi Hukum Islam Pasal 23 ayat (1) adalah apabila mempelai perempuan tidak mempunyai wali nasab sama sekali atau tidak mungkin menghadirkannya atau tidak diketahui tempat tinggalnya. Sedangkan berdasarkan Keputusan Menteri Agama No. 2 Tahun 1987 Pasal 2 Ayat (2) dinyatakan bahwa bagi calon mempelai wanita yang akan menikah di wilayah Indonesia atau di luar negeri/wilayah ekstra-teritorial Indonesia ternyata tidak mempunyai Wali Nasab yang berhak atau Wali 
Nasabnya tidak memenuhi syarat atau mafqud atau berhalangan atau adhal, maka nikahnya dapat dilangsungkan dengan Wali Hakim.

Pemohon dengan calon suami

Pemohon tidak termasuk dalam ketentuan pasal- pasal di atas, karenanya keengganan wali Pemohon tersebut tidak mempunyai alasan yang sah. Disebabkan wali Pemohon terbukti enggan/adhal menikahkan Pemohon dengan Calon Suami Pemohon, maka pernikahan keduanya dapat dilangsungkan dengan wali hakim sebagaimana dimaksud Pasal 23 Kompilasi Hukum Islam. Dalam kehidupan masyarakat, banyak terjadi praktek perkawinan dengan menggunakan wali hakim, yaitu pejabat yang oleh Menteri Agama atau pejabat yang ditunjuk olehnya untuk bertindak sebagai wali nikah bagi calon mempelai perempuan yang tidak mempunyai wali. Hal ini terjadi karena mempelai perempuan yang tidak mempunyai wali nasab sama sekali atau wali melakukan adhal atau menolak menjadi wali nikah.

Keterangan seperti ini sesuai dengan azas penentuan hukum atau menghilangkan kesulitan. Karena wanita akan melaksanakan pemikahan, tetapi tidak ada wali yang berhak untuk menikahkannya, maka untuk mengatasi kesulitan itu digunakan wali hakim. Demikian juga sesuai dengan azas taisir (mempermudah) dan tahfif (memperingan). Sehingga aturan seperti ini cocok sekali dan telah memenuhi konsep demi kemaslaha tan manusia.

Suatu perkawinan harus memenuhi adanya rukun dan syarat perkawinan, salah satu rukun perkawinan adalah adanya wali. Perkawinan tidak dapat dilangsungkan tanpa adanya seorang wali, karena dalam perkawinan tanpa hadirnya seorang wali maka perkawinan tersebut dapat dianggap tidak memenuhi rukun perkawinan. Berdasarkan pasal 20 Kompilasi Hukum Islam, wali dibedakan menjadi dua yaitu wali Nasab dan wali Hakim. Wali hakim dapat bertindak menjadi wali dalam perkawinan apabila wali nasab memang tidak ada, sedang berpergian jauh atau tidak ada ditempat, sedang berada di dalam penjara wali menjadi tahanan yang tidak boleh dijumpai, sedang berihram haji atau umrah, menolak atau berkeberatan bertindak sebagai wali, dan wali nasab yang ada tidak memenuhi syarat.

Menurut Pasal 1 Peraturan Menteri Agama Nomor 2 Tahun 1987, Wali Hakim adalah pejabat yang ditunjuk oleh Menteri Agama atau pejabat yang ditunjuk olehnya untuk bertindak sebagai wali nikah bagi calon mempelai wanita yang tidak mempunyai wali. Kedudukan wali hakim itu sama pentingnya seperti halnya wali bagi seorang wanita. Wali hakim dapat bertindak sebagai wali nikah dalam pelaksanaan akad nikah jika ada masalah yang terjadi pada wali yang paling berhak bagi wanita itu, atau bagi calon mempelai wanita yang tidak mempunyai wali. Wali Hakim berperan sebagai pengganti dari wali nasab ketika terhalang dalam pandangan hukum Islam dan peraturan perundang-undangan, atau menolak untuk melaksanakan ijab akad nikah (adhal) dalam perkawinan.

Penggunaan wali hakim adalah sah apabila wali nasab masih ada tetapi enggan atau 'Adhal dan tidak mengajukan keberatan atau pembatalan atas perkawinan tersebut. Wali hakim berperan untuk mengatasi kesulitan dalam perkawinan jika 
calon mempelai wanita tidak mempunyai wali nikah. Dengan adanya wali hakim yang menggantikan wali nikah bagi calon mempelai wanita tersebut, maka tujuan utama dari perkawinan akan tercapai. Wali hakim berfungsi untuk mempermudah dan memperingan dalam pelaksa naan perkawinan bagi wanita yang tidak mempunyai wali, hal ini untuk mendapatkan kemaslahatan bagi para pihak yang ada hubungannya dengan perkawinan tersebut. Setelah wali hakim tersebut menikahkan mempelai perempuan berdasarkan penetapan yang dikeluarkan oleh hakim Pengadilan Agama bahwa wali nasab dari mempelai perempuan tersebut dinyatakan adhal maka selesai sudah kewajibannya dan kewajiban sebagai wali hakim dicabut kembali oleh Hakim Pengadilan Agama. Sedangkan hak yang mungkin saja timbul dari pelaksanaan akad nikah yaitu sama dengan hak-hak yang dimiliki oleh wali nasabnya. Misalnya saja dalam hal membatalkan pernikahan tersebut apabila ternyata terdapat syarat-syarat yang belum dilengkapi atau dengan kata lain wali nasabnya juga ikut berhak membatalkan pernikahan tersebut.

Peraturan Menteri Agama Nomor 2 Tahun 1987 Pasal 6, disebutkan sebagai berikut:

Sebelum akad nikah dilangsungkan Wali Hakim meminta kembali kepada Wali Nasabnya untuk menikahkan calon mempelai wanita, sekalipun sudah ada penetapan Pengadilan Agama tentang adhalnya Wali; (2) Apabila Wali Nasabnya tetap adhal, maka akad nikah dilangsungkan dengan Wali Hakim. Sesuai Peraturan Menteri Agama Nomor 2 Tahun 1987 tentang wali hakim yaitu Kantor Urusan Agama Kecamatan selaku pegawai pencatat nikah dapat ditunjuk menjadi wali hakim dalam wilayahnya untuk menikahkan mempelai wanita dengan pria pilihannya. Hal ini sesuai dengan ketentuan Pasal 4 Peraturan Menteri Agama Nomor 2 Tahun 1987, yang menyebutkan: (1) Kepala Kantor Urusan Agama Kecamatan selaku Pegawai Pencatat Nikah ditunjuk menjadi Wali Hakim dalam wilayahnya untuk menikahkan mempelai wanita sebagai dimaksud Pasal 2 ayat (1) peraturan ini. (2) Apabila di wilayah kecamatan, Kepala Kantor Urusan Agama Kecama tan berhalangan atau tidak ada, maka Kepala Seksi Urusan Agama Islam atas nama Kepala Kantor Departemen Agama Kabupaten/Kotamadya diberi kuasa untuk atas nama Menteri Agama menunjuk Wakil/Pembantu Pegawai Pencatat Nikah untuk sementara menjadi Wali Hakim dalam wilayahnya.

3. Prosedur penetapan wali 'Adhal dalam Hukum Islam dan KHI.

Pengadilan Agama merupakan kerangka sistem dan tata hukum Nasional yang berdasarkan Pancasila dan Undang-Undang Dasar 1945, untuk mewujudkan peradilan yang sederhana, cepat dan biaya ringan. Peradilan Agama merupakan salah satu pelaksana kekuasaan kehakiman bagi rakyat pencari keadilan yang baragama Islam mengenai perkara perdata tertentu yang diatur dalam undang-undang ini.

Berlakunya undang-undang No. 7 tahun 1989 tentang peradilan agama, secara konstitusional Pengadilan Agama merupakan salah satu badan peradilan yang disebut dalam pasal 24 UUD 1945. Kedudukan dan kewenanga nnya adalah sebagai peradilan negara dan sama derajatnya dengan peradilan lainnya. Mengenai fungsi Peradilan Agama dibina dan diawasi oleh 
Mahkamah Agung sebagai Pengadilan Negara Tertinggi.

Tugas Pengadilan Agama bukan sekedar memutus perkara melainkan menyelesaikan sengketa sehingga terwujud pulihnya kedamaian antara pihak- pihak yang bersengketa, tercipta adanya rasa keadilan pada masing-masing pihak yang berperkara dan terwujud pula tegaknya hukum dan kebenaran pada perkara yang diperiksa dan diputus. Salah satu prinsip dari negara hukum adalah adanya legalitas formal, yaitu undang-undang sebagai dasar bernegara. Begitu juga dengan lembaga pengadilan, undang-undang menjadi hal paling esensial dalam sistem peradilan. Karena ia menjadi hukum materiil yang akan dipakai landasan dalam memutuskan perkara.

Perkawinan tidak dapat dilangsungkan tanpa adanya seorang wali, karena dalam perkawinan tanpa hadirnya seorang wali maka perkawinan tersebut dapat dianggap tidak memenuhi rukun perkawinan. Penetapan Majelis Hakim No. 005/Pdt.P/2012/PA.Skh mengabulkan permohonan pemohon bahwa wali yang menjadi wali nikah pemohon adalah wali adhal karena pemohon dapat membuktikan kebenaran permohonannya tersebut. Prosedur penetapan wali pengganti terhadap wali 'Adhal dilakukan dalam persidangan yang meliputi Pemanggilan pihak-pihak berperkara oleh Pengadilan Agama, Usaha perdamaian oleh Majelis Hakim, Pembacaan surat permohonan, Pemeriksaan persidangan, dan Pembacaan hasil penetapan majelis hakim.

Kedua, penetapan wali adhal /enggan berakibat perwaliannya pindah atau diganti oleh Wali Hakim. Hal ini sesuai dengan azas penentuan hukum atau menghilangkan kesulitan, azas taisir (mempermudah) dan tahfif (memperingan) sehingga memenuhi konsep demi kemaslahatan manusia. Berdasarkan Peraturan Menteri Agama Nomor 2 Tahun 1987 pejabat yang ditunjuk menjadi Wali Hakim adalah Kepala Kantor Urusan Agama Kecamatan selaku Pegawai Pencatat Nikah dan bila halangan diganti Kepala Seksi Urusan Agama Islam atas nama Kepala Kantor Departemen Agama Kabupaten/Kotamadya. Kedudukan Wali Hakim sebagai wali pengganti dari wali wanita memiliki fungsi menikahkan mempelai perempuan dengan calon mempelai laki-laki agar memenuhi persyaratan yang sah menurut Hukum dan perundangan-undangan yang berlaku. Selesai menikahkan mempelai berdua, kewajiban sebagai wali hakim dicabut kembali oleh Hakim Pengadilan Agama. Untuk lebih jelasnya perbedaan penetapan wali adhal menurut hukum Islam dan KHI dapat dilihat pada tabel dibawah ini:

Tabel 1: Perbedaan penetapan wali adhal menurut hukum Islam dan KHI

\begin{tabular}{|c|c|c|c|}
\hline No & Aspek & $\begin{array}{c}\text { HUKUM } \\
\text { ISLAM }\end{array}$ & KHI \\
\hline 1 & $\begin{array}{l}\text { Konsep } \\
\text { wali } \\
\text { adhal }\end{array}$ & $\begin{array}{l}\text { Menurut } \\
\text { humum } \\
\text { Islam Wali } \\
\text { 'adhal } \\
\text { ialah wali } \\
\text { nasab yang } \\
\text { mempuyai } \\
\text { kekuasaan } \\
\text { untuk } \\
\text { menikahkan } \\
\text { mempelai } \\
\text { wanita yang } \\
\text { berada } \\
\text { dibawah } \\
\text { perwalianny } \\
\text { a, tetapi } \\
\text { tidak biasa } \\
\text { atau tidak } \\
\text { mau } \\
\text { menikahkan } \\
\text { sebagai }\end{array}$ & $\begin{array}{l}\text { Wali adhal } \\
\text { atau enggan } \\
\text { adalah wali } \\
\text { yang berhak } \\
\text { menikahkan } \\
\text { anaknya tapi } \\
\text { tidak mau } \\
\text { menikahkann } \\
\text { ya dengan } \\
\text { penetapan } \\
\text { pengadilan } \\
\text { agama yang } \\
\text { merujuk } \\
\text { kepada } \\
\text { Undang- } \\
\text { undang } \\
\text { Nomor } 1 \\
\text { Tahun } 1974 \\
\text { dan KHI. }\end{array}$ \\
\hline
\end{tabular}




\begin{tabular}{|c|c|c|c|}
\hline & & $\begin{array}{l}\text { layaknya } \\
\text { seorang } \\
\text { wali } \\
\text { tersebut. }\end{array}$ & \\
\hline \multirow[t]{5}{*}{2} & \multirow[t]{5}{*}{$\begin{array}{l}\text { Prosedu } \\
\text { r } \\
\text { Penetap } \\
\text { an } \\
\text { wali } \\
\text { adhal }\end{array}$} & $\begin{array}{l}\text { Melalui } \\
\text { seorang } \\
\text { hakim } \\
\text { sebagai } \\
\text { penengah }\end{array}$ & $\begin{array}{l}\text { Pertama, } \\
\text { pemanggilan } \\
\text { pihak-pihak, } \\
\text { yaitu } \\
\text { pemohon dan } \\
\text { wali. }\end{array}$ \\
\hline & & $\begin{array}{l}\text { wali } \\
\text { Aqrabnya, } \\
\text { dan mana } \\
\text { kala wali } \\
\text { ab'ad tidak } \\
\text { bisa } \\
\text { menggantik } \\
\text { an nya, } \\
\text { maka hak } \\
\text { kewalianny } \\
\text { a diserah } \\
\text { kan kepada } \\
\text { wali } \\
\text { Hakim. }\end{array}$ & $\begin{array}{l}\text { Kedua, } \\
\text { usaha } \\
\text { perdamaian, }\end{array}$ \\
\hline & & \multirow{3}{*}{$\begin{array}{l}\text { Wali aqrab } \\
\text { ke wali } \\
\text { ab'ad } \\
\text { sampai } \\
\text { yang paling } \\
\text { jauh, jika } \\
\text { masih tetap } \\
\text { adhal maka } \\
\text { hak } \\
\text { kewalianny } \\
\text { a } \\
\text { diserahkan } \\
\text { kepada } \\
\text { hakim. }\end{array}$} & $\begin{array}{l}\text { Ketiga, } \\
\text { pembacaan } \\
\text { surat } \\
\text { permohonan, }\end{array}$ \\
\hline & & & $\begin{array}{l}\text { Keempat, } \\
\text { pemeriksaan } \\
\text { persidangan. }\end{array}$ \\
\hline & & & $\begin{array}{l}\text { Kelima, } \\
\text { pembacaan } \\
\text { hasil } \\
\text { penetapan } \\
\text { majelis } \\
\text { hakim. }\end{array}$ \\
\hline
\end{tabular}

\section{KESIMPULAN}

1. Konsep Wali Adhol dan dasar hukumnya dalam pernikahan Hukum Islam dan KHI adalah sebagai berikut : Menurut humum Islam Wali 'adhal ialah wali nasab yang mempuyai kekuasaan untuk menikahkan mempelai wanita yang berada dibawah perwaliannya, tetapi tidak biasa atau tidak mau menikahkan sebagai layaknya seorang wali tersebut.
Sedangkan menurut KHI wali adhal atau enggan adalah wali yang berhak menikahkan anaknya tapi tidak mau menikahkannya dengan penetapan pengadilan agama yang merujuk kepada Undang-undang Nomor 1 Tahun 1974 dan KHI.

2. Prosedur penetapan wali Adhol dalam Hukum Islam dan KHI. Adapun menurut hukum Islam adalah sebagai berikut;

a. Golongan hanafiah menyatakan bila wali adhal untuk menikahkan anaknya, dalam hal ini wali Aqrabnya, dan mana kala wali ab'ad tidak bisa menggantikannya, maka hak kewaliannya diserah kan kepada wali Hakim.

b. Sedangkan Syafi'iyah dan Malikiyah menyatakan bahwa penyelesaian pernikahan jika walinya adhol adalah melalui seorang hakim sebagai penengah

c. Golongan hambaliyah menyatakan bila seorang wali adhal dalam menikahkan anaknya maka hak kewalianya akan berpindah dari wali aqrab ke wali ab'ad sampai yang paling jauh, jika masih tetap adhal maka hak kewaliannya diserahkan kepada hakim.

3. Sedangkan Prosedur penetapan wali Adhol dalam KHI, mengacu kepada undang-undang no. 1/1974, KHI dan PMA No .30 tahun 2005 yaitu: Pertama, pemanggilan pihak-pihak, yaitu pemohon dan wali, Kedua, usaha perdamaian, Ketiga, pembacaan surat permohonan, Keempat, pemeriksaan persidangan, Kelima, pembacaan hasil penetapan majelis hakim.

\section{REFERENSI}

Abdul Jalil (ed), Fiqh Rakyat (Pertautan Figh dengan Kekuasaan), Yogyakarta:LKiS, 2000.

Abdurraḥmān al-Jazīīi, Kitāb al-Fiqih Alal Mażahib al-Arba'ah Beirut: Dar al-Fikr, tt

${ }^{1}$ Abdurrahman, Kompilasi Hukum Islamdi Indonesia, Jakarta: Akademika Pustaka Pressindo, 1992 
Abu Dawud Sulaiman bin Al-Asy'ats bin Ishaq bin Basyir Al-Azdiy As-Sijistani. Sunan Abi Dawud, cet. 1, juz. 4 Suriya: Darul Fikri,tt.

Ahmad Rofiq, Hukum Islam diIndonesia, Jakarta: PT.Raja Grafindo Persada, 1998

Ahrun Khoeruddin, Pengadilan Agama, Bandung: Citra Aditia Bakti, 1999

Al-Imām Ab̄̄ Abdillah Muhammad bin Idrīs Al-Syafi'̄̄, Al-Umm, cet-II Beirut: Darul Fikr, 1983

Al-Imām Syamsuddīn Abī Faraj Abdurraḥmān Ibnu Qudamah Almunqaddasi, alMugnī Wa Syarh al-Kabīr Beiurt: Darul Kutubil Ilmiyah, tt.

Al-Imām Syamsuddīn Abī Faraj Abdurraḥmān Ibnu Qudamah Almunqaddasi, alMugnī Wa Syarh al-Kabīr Beiurt: Darul Kutubil Ilmiyah, tt

Al-Tirmīzī, Sunan Al-Tirmīzī Beirut: Dār alFikr, tt

Amir Syarifuddin, Hukum Perkawinan di Indonesia, Jakarta: Kencana, 2006

Departemen Agama Republik Indonesia, $A l$ Qur'an Dan Terjemah, Semarang: Toha Putra, 2005

Fuad Mohd Fachruddin, Kawin Mut'ah Dalam Pandangan Islam, Jakarta: Pedoman Ilmu Jaya 2010

Ghazali Mukri, Panduan Fiqh Perempuan, Jogjakarta: Salma Pustaka, 2000

Ibn Rusyd, Bidāyah al-Mujtahid wa Nihāyah al-Muqtasid Beirut: Dār al-Fikr, t.t

Ibrâhîm al-Bâjûrî, Hâsyiah al-Bâjûrî 'alâ ‘ibn Qâsim al-Ghazzî, Surabaya: Hidâyah, tt.,

Imam al-Syarqâwî, Syarqâwî̀ 'alâ al-Tahrîr, Surabaya: al-Hidâyah, tt.

Jalâl al-Dîn al-Mahallî, Hâsyiah al-Mahallî 'alâ Minhâj al-Thâlibîn, Semarang: Thahâ Putra, tt

Jalāluddīn bin Muḥammad bin Aḥmad Al Maḥallī, Syarh Minhāj al-Talibin, cet IV Surabaya, Maktabah Nabhan, 1974.

Kementerian Agama RI, Kompilasi Hukum Islam (Buku 1 Hukum Perkawinan) dan Dalil-dalil Nash dan Kitab Fiqh, Jakarta : Kemenag RI, 2010

Lewis Mulfered Admsdkk, (ed.), Webster's World University Dictionary, Washington DC: Publisher Company Inc, 1965

M. Quraish Shihab, Tafsir Al-Mishbah: Pesan, Kesan dan Keserasian Al-Qur'an, Jakarta: LenteraHati,Vol. 2,2002.

Marzuki Wahid dan Rumadi, Fiqh Mazhab Negara,Yogyakarta: LKIS, 2001

Muhammad al-Syirbînî al-Khathîb, al-'Iqnâ' Surabaya: al-Hidâyah, $\mathrm{tt}$

Muhammad Khotib al-Sarbani, Al-Mughnil Muhtaj, juz 4, Beirut Libanon: Dar al-Kutubi Ilmiah, tt
Sayyid Sabiq, Fikih Sunnahditejemahkan oleh Mohammad Thalib, Bandung : PT. alMa'arif, 1980

Subekti, Hukum Keluarga dan Hukum Waris, Jakarta:Penerbit PT.Intermasa, 2002

Sudikno Mertokusumo, Hukum Acara Perdata Indonesia, Yogyakarta: Liberty, 2006

Sulaiman Rasjid, Fiqh Islam, Bandung: CV Sinar Baru,Cet.Ke-25, 1992

Sulaiman Rasyid, FiqhIslam, Bandung: Sinar Baru Algesindo,cet. 37, 2004

Syaikh Abd al-Rahman al-Jazîrî, al-Fiqh 'alâ alMadzâhib al-'Arba'at, Beirut : Dar al- Fikr, tt,

Syeikh Muhammad Ali Ash-Shabuny, Az-Zawaju Islamil Mubakkrir: Sa'adah,Terj. Mustaqiim, Hadiah untuk Pengantin, Jakarta: Mustaqim,Cet.1, 2001.

Taufiq, Justisia, Indahnya Kawin Sesama Jenis, Edisi25, Semarang 2004

Tim Penyusun Kamus Penelitian dan Pengembangan Bahasa, Kamus Besar Bahasa Indonesia, Jakarta: Balai Pustaka,1989 